\title{
Perceived community support about the implementation of a smoke-free environment regional regulations in the Tegal municipality
}

\author{
MEITA VERUSWATI 1, 2, A, B, D, F, G, AL ASYARY'2, 3, A-F, EDI SUCIPTO
ORCID ID: 50 5, A, B, D,
ORCID ID: 0000-00003-2150-0429 \\ WAHYU SULISTIADI 2, 6, E, F, ABDILLAH AHSAN7, A, D, G \\ ${ }^{1}$ Department of Public Health Science, Faculty of Health Sciences, Universitas Muhammadiyah Prof. Dr. Hamka \\ (UHAMKA), Jakarta, Indonesia \\ ${ }^{2}$ Centre for Educational and Community Services, Faculty of Public Health, Universitas Indonesia (P3M FKM UI), \\ Depok, Indonesia \\ ${ }^{3}$ Department of Environmental Health, Faculty of Public Health, Universitas Indonesia, Depok, Indonesia \\ ${ }^{4}$ District Health Office, the Local Government of Tegal Municipality, Slawi, Indonesia \\ ${ }^{5}$ Bhakti Mandala Husada Tegal School of Health Sciences, Slawi, Indonesia \\ ${ }^{6}$ Department of Health Administration and Policy, Faculty of Public Health, Universitas Indonesia \\ ${ }^{7}$ Faculty of Economic and Business, Universitas Indonesia, Depok, Indonesia
}

A - Study Design, B - Data Collection, C - Statistical Analysis, D - Data Interpretation, E - Manuscript Preparation, F - Literature Search, G - Funds Collection

Summary Background. A smoke-free environment regional regulation is expected to greatly decrease the negative impact of cigarette smoking in public places; however, community perception of the regulation prior to its implementation remains unclear. Objectives. This research aims to determine community perception and support for the implementation of a smoke-free environment regional regulation in the Tegal municipality.

Material and methods. A quantitative study with a cross-sectional approach was conducted in seven zones identified as smoke-free environments under Government Act No. 36 of 2009. Perception and support were determined through surveys using an accidental sampling framework. A total of 226 samples were collected to explore community perception of the demands, obstacles and opportunities surrounding the implementation of a smoke-free environment regional regulation in the Tegal municipality.

Results. This study shows that $84.50 \%$ of the respondents agreed with $(84.50 \%)$ and completely $(84.96 \%)$ supported the implementation of a smoke-free environment regulation in the Tegal municipality. In fact, most of the respondents with an active smoking status (62.50\%) also agreed with and supported this regulation. Support for implementation of a smoke-free environment regional regulation was mainly determined by age group. The elderly and adult age group supported the implementation of such a regulation more than the adolescent age group. Furthermore, respondents with fair knowledge, attitude and commitment were 14 times more supportive of the implementation than those with poorer knowledge, attitude and commitment.

Conclusions. This research shows that those with an active smoking status also support this regional regulation, which indicates that active smokers understand the importance of protecting people around them from cigarette smoking.

Key words: public health, tobacco, Indonesia.

Veruswati M, Asyary A, Sucipto E, Sulistiadi W, Ahsan A. Perceived community support about the implementation of a smoke-free environment regional regulations in the Tegal municipality. Fam Med Prim Care Rev 2020; 22(3): 222-227, doi: https://doi.org/10.5114/ fmpcr.2020.98250.

\section{Background}

In an effort to control tobacco consumption, Indonesia has implemented regulations in line with the smoke-free environment policy under the Indonesian government's Act No. 36 of 2009, article 115, paragraph 1 , in seven environments/zones [1]. These environments consist of health-care facilities, learning and educational places, kids' playgrounds, worship locations, public transport, workplaces and other public zones. In article 2 of this regulation, the government also mandates every local government to identify smoke-free environments in their territories [1]. Smoke-free environments are any zones where smoking, producing, selling, advertising and promoting tobacco products are prohibited $[2,3]$.
The establishment of Indonesia's smoke-free zones has become the only real effort to protect those who suffer from the negative impact of smoking, especially second-hand smokers [2]. However, only 111 of 518 municipalities have implemented this smoke-free zone regulation [4]. Meanwhile, only 9 of 35 municipalities in the Jawa Tengah province have set smoke-free zones, and Tegal is one of those that have yet to implement the policy [5].

Through mass media and grassroot communities, Tegal citizens have expressed their desire for smoke-free fresh air, especially in public spaces [5]. The Tegal municipality has an immense opportunity to successfully implement the smoke-free zone regulation, as most of its population are sympathisers of Nahdlatul Ulama (NU), an organisation that promotes health discipline activities. Fatayat NU, NU's official organisation for 
women, has long been known for spearheading activities that champion health promotion and encourage communities to demand a smoke-free zone policy as a preliminary effort in gaining a thriving territory for mankind $[6,7]$.

On the other hand, smokers believe that their habit would not have a negative impact on their health. They state that by having a particular kind of cigarette, smoking would be safe for their health and the health of others [8]. Subsequently, overestimation of lifetime smoking appears to alleviate the effects of environmental smoking (peers, best friends and parents) among adolescents [9]. Specifically, strong and consistent perceptionlevel evidence shows that willingness to smoke is associated with a smoke-free environment policy. It increases smoking cessation and decreases cigarette consumption among adult smokers [10].

\section{Objectives}

This study demonstrates the need for smoke-free zones in the Tegal municipality, which have not been initiated by any parties yet. This research aims to determine community perception and support for the implementation of a smoke-free environment regulation in the Tegal municipality.

\section{Material and methods}

\section{Study design}

A quantitative study with a cross-sectional approach was conducted in seven zones identified as smoke-free environments under Government Act No. 36 of 2009.

\section{Setting}

Seven areas of smoke-free zones comprised of health care facilities, educational places, playgrounds, worships, mass transportations, workplaces and public places. The Tegal municipality is a rural area located in the Central Java province of Indonesia. The study was initiated in September 2017 and approved in early October 2017. The duration was three months, from mid-October to December 2017.

\section{Participants}

The eligibility criteria for this study consist of the following: (a) the participant resides in one of the seven areas of the study's setting, (b) the participant is a registered Tegal municipality citizen, (c) the participant is 18 years of age or older and (d) the participant consents to participate in the study by signing a letter of informed consent. All these criteria were required from each participant.

\section{Variables}

This study has two variables: (1) independent variables, which include characteristics (age, gender, education level, occupation and smoking status) and knowledge, attitude and commitment of the respondents, as well as (2) the support of the respondents. The operational definition of the variables takes into account the demographic information of the participants, which may reflect their exact perception (knowledge, attitudes and commitment) of the implementation of a smoke-free environment policy in the Tegal municipality.

\section{Data sources/measurement}

The characteristics of the respondents were measured using a demographic-structured questionnaire, while their perceptions were determined using a Likert scale quantitative-structured perception questionnaire.

\section{Bias}

As this research was using a cross-sectional, this research's study design has disadvantage of measuring exact outcomes from exposure with a one-shot time measurement of independent and dependent variables, data collection for this study is concerned with the research instrument. A quantitative-structured questionnaire was previously tested using a validity and reliability assessment in other settings. The validity and reliability assessment of the research instrument was determined using Cronbach's alpha. The result showed that the items in the questionnaire are valid and reliable and would obtain appropriate and constant information for the study.

\section{Study size}

A total of 226 samples were selected for this study, which represented all of the Tegal municipality's communities as part of a population study. Accidental random sampling with a WHOLemeshow sample size obtained 210 samples with $10 \%$ added, hindering abnormal data distribution (outlier effects).

\section{Quantitative variables and statistical methods}

Multiple logistic regression was performed to analyse the data set and check its normality distribution and interaction and determined whether confounding existed. This research was conducted from October to December 2017 and was granted ethical approval legally by the Health Ethical Committee of Muhammadiyah University of Prof. Dr. Hamka: No. 145/KEK/IV/2017.

\section{Results}

\section{Participants, descriptive data and outcome data}

\section{Respondents characteristics}

A total of 113 , or $43.6 \%$, of the samples had graduated from high school, while $7.5 \%$ did not have formal education. 72 of them also had worked as entrepreneurs, while 50 were not working or students. The number of respondents with an active smoker status was 92 , or $40.7 \%$, while that of the non-smokers was 134 , or $59.3 \%$ (Table 1 ).

\begin{tabular}{|l|l|l|}
\hline \multicolumn{2}{|l|}{ Table 1. Characteristics of respondents } \\
\hline Characteristics & $\begin{array}{l}\text { Amount } \\
(n=226)\end{array}$ & $\begin{array}{l}\text { Propor- } \\
\text { tion (\%) }\end{array}$ \\
\hline $\begin{array}{l}\text { Age } \\
\text { adolescent ( } \leq 9 \text { years old) }\end{array}$ & 17 & 7.5 \\
adult (20-55 years old) & 188 & 83.2 \\
elderly ( $\geq 56$ years old) & 21 & 9.3 \\
\hline $\begin{array}{l}\text { Gender } \\
\text { male }\end{array}$ & 170 & \\
female & 56 & 75.2 \\
\hline Educational level & & \\
did not graduate elementary school & 17 & 7.5 \\
elementary school & 19 & 8.4 \\
junior high school & 39 & 17.3 \\
senior high school & 113 & 50.0 \\
higher education (diploma and above) & 38 & 16.8 \\
\hline Occupational status & & \\
not working/students & 50 & 22.1 \\
civil servant/police/military & 32 & 14.2 \\
entrepreneur & 72 & 31.9 \\
private sector employee & 71 & 31.4 \\
retired & 1 & 0.4 \\
\hline Smoking status & & \\
yes & 92 & 40.7 \\
no & 134 & 59.3 \\
\hline
\end{tabular}




\section{Knowledge, attitude, commitment and support}

Based on the results below, most of the respondents have poor knowledge and attitude toward the smoke-free environment regulation. However, most of them are willing to be fostered as a form of approval and support for the smoke-free environment regulation (Table 2).

\begin{tabular}{|c|c|c|}
\hline $\begin{array}{l}\text { Knowledge, attitude, commitment and } \\
\text { support }\end{array}$ & $\begin{array}{l}\text { Amount } \\
(n=226)\end{array}$ & $\begin{array}{l}\text { Percent- } \\
\text { age (\%) }\end{array}$ \\
\hline $\begin{array}{l}\text { Knowledge about smoke-free environ- } \\
\text { ments } \\
\text { poor } \\
\text { fair }\end{array}$ & $\begin{array}{l}145 \\
81\end{array}$ & $\begin{array}{l}64.2 \\
35.8 \\
\end{array}$ \\
\hline $\begin{array}{l}\text { Attitude toward smoke-free environments } \\
\text { poor } \\
\text { fair }\end{array}$ & $\begin{array}{l}165 \\
61 \\
\end{array}$ & $\begin{array}{l}73.0 \\
27.0 \\
\end{array}$ \\
\hline $\begin{array}{l}\text { Will attend if there is any socialisation } \\
\text { about the implementation of the smoke- } \\
\text {-free environment regulation } \\
\text { yes } \\
\text { no }\end{array}$ & \begin{tabular}{|l|l}
155 \\
71
\end{tabular} & $\begin{array}{l}68.6 \\
31.4 \\
\end{array}$ \\
\hline $\begin{array}{l}\text { Will allow an officer to visit and imple- } \\
\text { ment the smoke-free environment } \\
\text { regulation } \\
\text { yes } \\
\text { no } \\
\end{array}$ & $\begin{array}{l}158 \\
68 \\
\end{array}$ & $\begin{array}{l}69.9 \\
30.1 \\
\end{array}$ \\
\hline $\begin{array}{l}\text { Will entirely approve of the implemen- } \\
\text { tation of the smoke-free environment } \\
\text { regulation } \\
\text { yes } \\
\text { no } \\
\end{array}$ & \begin{tabular}{|l|l}
191 \\
35
\end{tabular} & $\begin{array}{l}84.5 \\
15.5 \\
\end{array}$ \\
\hline $\begin{array}{l}\text { Will support if there are any efforts } \\
\text { around the neighbourhood about the } \\
\text { smoke-free environment regulation } \\
\text { yes } \\
\text { no }\end{array}$ & $\begin{array}{l}168 \\
58\end{array}$ & $\begin{array}{l}74.3 \\
25.7\end{array}$ \\
\hline $\begin{array}{l}\text { Will entirely support the implementation } \\
\text { of the smoke-free environment regulation } \\
\text { yes } \\
\text { no }\end{array}$ & $\begin{array}{l}192 \\
34\end{array}$ & $\begin{array}{l}85.0 \\
15.0\end{array}$ \\
\hline
\end{tabular}

\section{Main results}

\section{Inferential analysis of the perception of community support}

Age was the most dominant characteristic in the status of support for the implementation of the smoke-free environment regulation in the Tegal municipality. The elderly and adults showed higher support (19.5 and 9 times higher, respectively) compared with the young age group. However, the majority (70.6\%) of young people tended to support the existence of the policy (Table 3).

Meanwhile, the number of non-smokers in the Tegal municipality who supported the implementation of the smoke-free environment regulation was 10 times greater than that of smokers. However, based on existing proportions, $65.2 \%$, or most smokers in the Tegal municipality, agreed to the enactment of the smoke-free environment regulation. Active smokers' awareness of the importance of protecting the people surrounding them from the dangers caused by cigarette smoking was highly valued based on the results of the study.

In addition, willingness to be fostered at home by officers as a form of commitment had an impact that resulted in support that was eight times higher for the implementation of the smoke-free environment regulation in the Tegal municipality compared with those who were not committed. Likewise, fair knowledge and attitude, which were 6 and 14 times higher, respectively, indicated greater support for the existence of the regulation compared with those who fared poorly in these variables. This shows that the people of the Tegal municipality are well informed, behaved and committed to fully supporting the implementation of the smoke-free environment regulation in their municipality (Table 3).

\section{Discussions}

\section{Key results}

This study shows that most smokers are those with aged above 20 years old. As regards employment status, active smokers tend to work as private employees and have high school education. These results indicate that each individual has rights guaranteed by the constitution as regards obtaining education and decent work for their livelihood. Studies on socioeconomic characteristics indicate that an individual's attitude or behaviour is formed by adapting and giving rise to a constellation of behaviours in society $[11,12]$.

The tendency and distribution of the active status of smokers in public areas in the Tegal municipality reinforces the paradigm that smoking is associated with the socioeconomic capacity of each individual and is not categorised by cultural assimilation. In other words, smoking is not a culture that arises as a norm and a value of the people of the Tegal municipality, but rather as a deviant behaviour of each individual.

\section{Limitations of the study}

The research design cannot accommodate the precise perceptions of all stakeholders in the Tegal community. These perceptions are usually reflected by the local government of the Tegal municipality and mass organisations, which are composed of nongovernment and religious organisations, such as Muhammadiyah, NU, Fatayat NU, Muslimat NU and so on. However, this study comprehensively provides segmented community perceptions that were randomly obtained from seven smoke-free environments. This information could serve as a guide in looking for stakeholders' perspectives and providing sufficient information to prepare family doctors who initiate smoking cessation programmes in the community.

\section{Interpretation}

This study shows the recessive proportion of active smokers in adolescence ( $<19$ years); however, even the smallest percentage will always be a focus in controlling the adverse effects of smoking [13-15]. This population, targeted by the tobacco industry, provides a very important bargaining pattern in policies surrounding tobacco control around the world [16, $17]$, including Indonesia [18, 19]. In fact, restricting the sale of cigarette based on age and open commercial trade in stores is still ineffectively conducted which the sale of cigarette per cigar by the non-formal roadside supplier without age restriction (ketengan) is a real day-to-day practice in most parts on Indonesia [20], a country that has not ratified the Framework Convention on Tobacco Control.

This study shows that adult and advanced age, passive smoking status, good knowledge, good attitude and willingness to be fostered in the framework of implementing the smoke-free environment regulation are factors that support the implementation of the regulation in the Tegal municipality. Support for the implementation of a system or regulation will always be influenced by the characteristics, level of knowledge and education of each individual $[21,22]$. The characteristics of individuals in this study, such as age and smoking status, are significantly associated with support for the smoke-free environment regulation. 


\begin{tabular}{|c|c|c|c|c|c|c|c|c|}
\hline \multirow[t]{2}{*}{ Variables } & \multicolumn{2}{|c|}{$\begin{array}{l}\text { Entirely supports the } \\
\text { implementation of the } \\
\text { smoke-free environ- } \\
\text { ment regulation }\end{array}$} & \multicolumn{3}{|c|}{ Chi-square (bivariate) } & \multicolumn{3}{|c|}{$\begin{array}{l}\text { Multiple logistic regression } \\
\text { (multivariate) }\end{array}$} \\
\hline & No. & Yes & $p$ & $\mathbf{P R}_{\text {crude }}$ & $\mathrm{Cl} 95 \%$ & $p$ & $\mathbf{P R}_{\text {adi }}$ & Cl $95 \%$ \\
\hline $\begin{array}{l}\text { Age } \\
\text { adolescent ( } \leq 19 \text { years old) } \\
\text { adult ( } 20-55 \text { years old) } \\
\text { elderly ( } \geq 56 \text { years old) }\end{array}$ & \begin{tabular}{|l|}
$5(29.4)$ \\
$28(14.9)$ \\
$1(4.8)$ \\
\end{tabular} & $\begin{array}{l}12(70.6) \\
160(85.1) \\
20(95.2) \\
\end{array}$ & $\begin{array}{l}0.133 \\
0.128 \\
0.066 \\
\end{array}$ & $\begin{array}{l}\text { Ref } \\
2.381 \\
8.333 \\
\end{array}$ & $\begin{array}{l}\text { Ref } \\
0.779-7.282 \\
0.867-80.113 \\
\end{array}$ & \begin{tabular}{|l|}
0.039 \\
0.016 \\
0.043 \\
\end{tabular} & $\begin{array}{l}\text { Ref } \\
9.116 \\
19.476 \\
\end{array}$ & $\begin{array}{l}\text { Ref } \\
1.512-54.967 \\
1.098-345.364 \\
\end{array}$ \\
\hline $\begin{array}{l}\text { Gender } \\
\text { male } \\
\text { female }\end{array}$ & \begin{tabular}{|l}
$34(20.0)$ \\
$0(0.0)$
\end{tabular} & $\begin{array}{l}136(80.0) \\
56(100.0)\end{array}$ & 0.001 & 0.800 & $0.742-0.862$ & NA & NA & NA \\
\hline $\begin{array}{l}\text { Educational level } \\
\text { did not graduate elementary } \\
\text { school } \\
\text { elementary school } \\
\text { junior high school } \\
\text { senior high school } \\
\text { higher education (diploma } \\
\text { and above) }\end{array}$ & $\begin{array}{l}0(0.0) \\
4(21.1) \\
6(15.4) \\
21(18.6) \\
3(7.9) \\
\end{array}$ & $\begin{array}{l}17(100.0) \\
15(78.9) \\
33(84.6) \\
92(81.4) \\
35(92.1) \\
\end{array}$ & $\begin{array}{l}0.629 \\
0.998 \\
0.998 \\
0.998 \\
0.998 \\
0.998 \\
\end{array}$ & $\begin{array}{l}0.000 \\
0.000 \\
0.000 \\
0.000 \\
0.000 \\
0.000 \\
\end{array}$ & $\begin{array}{l}\text { 0.000-NA } \\
0.000-\mathrm{NA} \\
0.000-\mathrm{NA} \\
0.000-\mathrm{NA} \\
0.000-\mathrm{NA} \\
0.000-\mathrm{NA} \\
\end{array}$ & NA & NA & NA \\
\hline $\begin{array}{l}\text { Occupational status } \\
\text { not working } \\
\text { worker }\end{array}$ & $\begin{array}{l}5(10.0) \\
29(16.5)\end{array}$ & $\begin{array}{l}45(90.0) \\
147(83.5)\end{array}$ & 0.365 & 0.607 & $0.248-1.486$ & NA & NA & NA \\
\hline $\begin{array}{l}\text { Smoking status } \\
\text { yes } \\
\text { no }\end{array}$ & $\begin{array}{l}31(33.7) \\
3(2.2) \\
\end{array}$ & $\begin{array}{l}61(66.3) \\
131(97.8)\end{array}$ & 0.000 & 15.051 & $4.742-47.770$ & 0.002 & 10.199 & $2.383-43.648$ \\
\hline $\begin{array}{l}\text { Knowledge about smoke-free } \\
\text { environments } \\
\text { poor } \\
\text { fair }\end{array}$ & \begin{tabular}{|l|}
$32(22.1)$ \\
$2(2.5)$ \\
\end{tabular} & $\begin{array}{l}113(77.9) \\
79(97.5) \\
\end{array}$ & 0.000 & 8.938 & $2.199-36.334$ & 0.028 & 6.177 & $1.211-31.491$ \\
\hline $\begin{array}{l}\text { Attitude toward smoke-free } \\
\text { environments } \\
\text { poor } \\
\text { fair }\end{array}$ & \begin{tabular}{|l|}
$33(20.0)$ \\
$1(1.6)$ \\
\end{tabular} & $\begin{array}{l}132(80.0) \\
60(98.4) \\
\end{array}$ & 0.001 & 12.200 & $1.705-87.276$ & 0.018 & 14.040 & $1.575-125.195$ \\
\hline $\begin{array}{l}\text { Will attend if there is any } \\
\text { socialisation about the imple- } \\
\text { mentation of the smoke-free } \\
\text { environment regulation } \\
\text { yes } \\
\text { no }\end{array}$ & $\begin{array}{l}24(33.8) \\
10(6.5)\end{array}$ & $\begin{array}{l}47(66.2) \\
145(93.5)\end{array}$ & 0.000 & 5.329 & $2.649-10.364$ & NA & NA & NA \\
\hline $\begin{array}{l}\text { Will allow an officer to visit } \\
\text { and implement the smoke-free } \\
\text { environment regulation } \\
\text { yes } \\
\text { no }\end{array}$ & $\begin{array}{l}25(36.8) \\
9(5.7)\end{array}$ & $\begin{array}{l}43(63.2) \\
149(94.3)\end{array}$ & 0.000 & 6.454 & $3.183-13.087$ & 0.000 & 8.090 & 2.856-22.913 \\
\hline
\end{tabular}

PR - prevalence ratio; $\mathrm{Cl}$ - confidence interval; Ref - reference; NA - not available.

Similar to the approval factor for the implementation of the smoke-free environment regulation, an active smoking status is significantly related to not supporting the regulation's implementation. This support will usually be followed by the process of agreeing. Based on the concept of behaviour, an individual activity that will influence the community is based on trigger factors and reinforcement [23]. The behaviour of not supporting the implementation of the smoke-free environment regulation is due to disapproval, which has been explained according to previous findings, where the natural factors described above are the cause of active smokers disagreeing with the regulation.

Likewise, the status of knowledge lacks support for the implementation of the smoke-free environment regulation. This result agrees with previous findings as a factor that determines agreement with the implementation of the policy in the Tegal municipality. The tendency to agree with and support the implementation is determined by the status of community knowledge [14]. Besides the importance of socialisation for this issue, as discussed above, increasing knowledge about tobacco regulation and control will also determine the health service behaviour taken (health-seeking behaviour), especially for primary health services [24].

\section{Generalisability}

The Tegal municipality is a rural area in the Central Java province in Indonesia [5]. This province is the third biggest community in the country, which is enough to represent the most populous community in Indonesia [25]. At the same time, Indonesia is also known as a progressive country that is step-by-step experiencing sustainable economic development, which is related to the tobacco control programme and the community's perception of it $[26,27]$. Since this study was conducted in a middle-income country, its findings can be generalised in similar settings in most Asian, South American and Eastern European countries $[28,29]$, including Poland, which have had 
harmonious bilateral collaboration for more than 66 years with Indonesia [30]. Furthermore, Indonesia and Poland have an identical democratic process order [31], cultural richness and country symbolisation [32].

\section{Conclusions}

This research is the first study about tobacco control in the Tegal Raya Regency. It shows that all components of a community, including most smokers, completely support the implementation of the smoke-free environment regulation in the
Tegal municipality. Furthermore, a study is needed to explore policymakers' perceptions about the full implementation of the regulation in the Tegal municipality.

Acknowledgments. This study was funded by the Indonesian Tobacco Control Research Network, Bloomberg - John Hopkins School of Public Health, collaborating with the Demographic Institute, University of Indonesia (LD FE-UI). We would like to thank the Tegal municipality local government, the contributors and our field enumerators: Mr. Didik Rianto, Ms. Agustin Putri and Ms. Tesya.

This study was funded by the Indonesian Tobacco Control Research Network, John Hopkins Bloomberg School of Public Health, collaborating with the Demographic Institute, Universitas Indonesia (LD FE-UI). The publication is also supported by the PUTI Q3 2020 Grant, Directorate for Research and Development, Universitas Indonesia (Risbang UI), No. NKB-1932/UN2.RST/HKP.05.00/2020 (Recipient - Dr. Al Asyary). Conflicts of interest: The authors declare no conflicts of interest.

\section{References}

1. Republic of Indonesia Government. Government Act No. 36 about Health (Undang-Undang Republik Indonesia No. 36 Tentang Kesehatan). Jakarta, Indonesia: Republic of Indonesia Government; 2009.

2. Asyary A, Veruswati M. Compliance study of hotel and nightclub smoke-free zones in Bogor City, Indonesia. Tob Prev Cessat 2018; 4(25): $1-3$.

3. Asyary A, Veruswati M, Sulistiadi W. Hotel and Nightclub Development: a reflected perspective of Smoke-Free Zone (SFZ) implementation in Bogor City, Indonesia. Public Heal Indones 2017; 3(4): 142-144.

4. Kemenkes-RI. Aliansi bupati/walikota dalam pengendalian masalah kesehatan akibat tembakau dan penyakit tidak menular. Bul Jendela Data dan Inf Kesehat 2012; 2. Available from URL: https://www.kemkes.go.id/article/print/17071200002/pertemuan-aliansibupati-walkota-peduli-kawasan-tanpa-tembakau.html (in Indonesian).

5. Dinas Kesehatan Kabupaten Tegal. Profil Kesehatan Kabupaten Tegal [Internet]. Dinas Kesehatan Kabupaten Tegal. Slawi: Kementerian Kesehatan Republik Indonesia; 2016. Available from URL: https://www.google.com/url?sa=t\&rct=j\&q=\&esrc=s\&source=web\&cd=1\& cad=rja\&uact=8\&ved=2ahUKEwifwJTugp7IAhXyILcAHbHZBKoQFjAAegQIABAC\&url=http\%3A\%2F\%2Fwww.depkes.go.id\%2Fresources \%2Fdownload\%2Fprofil\%2FPROFIL_KAB_KOTA_2015\%2F3328_Jateng_Kab_Tegal_2015.pdf\&usg=AOvVaw3pFdtfvRP3Qio14yhJh2W_ (in Indonesian).

6. Mubarok Z. Gender-based religious democracy: a study of Umi Azizah's winning and women political movement of Tegal Regent election in 2018. In: SHS Web of Conferences. EDP Sciences; 2018: 2009.

7. Arofah N. Peran Muslimat NU dalam Pemberdayaan Perempuan (Studi kasus: Muslimat NU Desa Tuwel Kabupaten Tegal). J Polit Gov Stud. 2018; 7(2): 51-60 (in Indonesian).

8. Shpakou A, Kovalevskiy V, Klimatskaia L, et al. Traditional smoking and e-smoking among medical students and students-athletes popularity and motivation. Fam Med Prim Care Rev Prim Care Rev 2018; 20(1): 61-66, doi: 10.5114/fmpcr.2018.73705.

9. Otten R, Engels RCME, Prinstein MJ. A Prospective study of perception in adolescent smoking. J Adolesc Heal 2009; 44(5): 478-484, doi: https://doi.org/10.1016/j.jadohealth.2008.09.004

10. Mills AL, Messer K, Gilpin EA, et al. The effect of smoke-free homes on adult smoking behavior: a review. Nicotine Tob Res 2009; 11(10): 1131-1141, doi: 10.1093/ntr/ntp122.

11. Elgar FJ, Pförtner T-K, Moor I, et al. Socioeconomic inequalities in adolescent health 2002-2010: a time-series analysis of 34 countries participating in the health behaviour in school-aged children study. Lancet 2015; 385(9982): 2088-2095.

12. Hill S, Amos A, Clifford D, et al. Impact of tobacco control interventions on socioeconomic inequalities in smoking: review of the evidence. Tob Control 2014; 23(e2): e89-e97.

13. Pechmann C. Does antismoking advertising combat underage smoking? A review of past practices and research. In: Goldberg ME, Fishbein M, Middlestadt SE, eds. Social Marketing. New York: Routledge; 2018: 189-216.

14. Schneider SK, Buka SL, Dash K, et al. Community reductions in youth smoking after raising the minimum tobacco sales age to 21 . Tob Control 2016; 25(3): 355-359.

15. Robertson L, Cameron C, McGee R, et al. Point-of-sale tobacco promotion and youth smoking: a meta-analysis. Tob Control 2016; 25(e2): e83-e89.

16. Arrazola RA, Singh T, Corey CG, et al. Tobacco use among middle and high school students-United States, 2011-2014. MMWR Morb Mortal Wkly Rep 2015; 64(14): 381-385.

17. Fryer CS, Seaman EL, Clark RS, et al. Mixed methods research in tobacco control with youth and young adults: a methodological review of current strategies. PLOS ONE 2017; 12(8): e0183471.

18. Astuti PAS, Assunta M, Freeman B. Raising generation 'A': a case study of millennial tobacco company marketing in Indonesia. Tob Control 2018; 27(e1): e41-e49.

19. Septiono W, Ng N, Kuipers M, et al. Did local smoke free policy in Indonesia prevent youth from smoking? Tob Induc Dis 2018; 16(Suppl. 1): A149, doi: 10.18332/tid/83829.

20. Sebayang SK, Dewi DMSK, Ahsan A. Mixed-methods evaluation of a ban on tobacco advertising and promotion in Banyuwangi District, Indonesia. Tob Control 2019; 28(6): 651-656.

21. Hughes J, Smith LS, Garrett-Wright D. Brief intervention on nurses' knowledge and behavior regarding smoking cessation. J Nurses Prof Dev 2018; 34(5): 257-262.

22. Abu Shomar RT, Lubbad IK, El Ansari W, et al. Smoking, awareness of smoking-associated health risks, and knowledge of national tobacco legislation in Gaza, Palestine 2014. Cent Eur J Public Health 2014; 22(2): 80-89.

23. Prestwich A, Webb TL, Conner M. Using theory to develop and test interventions to promote changes in health behaviour: evidence, issues, and recommendations. Curr Opin Psychol 2015; 5: 1-5.

24. Veruswati M, Asyary A, Nadjib M, et al. Current activities in smokes-free zone policy: a tobacco control care reviews in Indonesia. Fam Med Prim Care Rev 2018; 20(4): 10-13. 
25. Pambudi EW, Miyasto M. Analisis pertumbuhan ekonomi dan faktor-faktor yang mempengaruhi (Kabupaten/kota Di Provinsi Jawa Tengah). Diponegoro J Econ 2013; 2(2): 51-61 (in Indonesian).

26. Barber S, Ahsan A. The tobacco excise system in Indonesia: hindering effective tobacco control for health. J Public Health Policy 2009; 30(2): 208-225.

27. Ahsan A, Wiyono NH, Setyonaluri D, et al. Illicit cigarette consumption and government revenue loss in Indonesia. Global Health 2014; 10(1): 75.

28. Temouri Y, Driffield N, Bhaumik SK. A strategic perspective of cross-listing by emerging market firms: Evidence from Indonesia, Mexico, Poland and South Africa. J Int Manag 2016; 22(3): 265-279.

29. Fowler E. Advancing reproductive rights in a religious world: a comparative survey of reproductive rights in Poland, Indonesia and Israel [A thesis submitted in conformity with the requirements for the degree of Master of Laws] University of Toronto; 2013.

30. Wnukowski D. Indonesia's potential as a stronger partner of Poland in Asia. Warszawa: Polski Instytut Spraw Międzynarodowych; 2015.

31. Petrova T. How Poland promotes democracy. J Democr 2012; 23(2): 133-147.

32. Majerska B. Comparative analysis of public facilities in Indonesia and in Poland, based on cultural values. Cultural center design in a public space of Surabaya. Warszawa: Zakład Architektury Współczesnej, Wnętrz i Form Przemysłowych; 2018.

Tables: 3

Figures: 0

References: 32

Received: 19.09 .2019

Reviewed: 24.09 .2019

Accepted: 26.02 .2020

Address for correspondence:

Dr. Al Asyary

Department of Environmental Health

Faculty of Public Health

Universitas Indonesia

C Building $2^{\text {nd }}$ Floor, Campus FKM-UI

Depok 16424

Indonesia

Tel.: +62 21-7863479

Email: al.asyary@ui.ac.id 